\title{
HUMAN VACCINIA-LIKE VIRUS OUTBREAKS IN SÃO PAULO AND GOIÁS STATES, BRAZIL: VIRUS DETECTION, ISOLATION AND IDENTIFICATION
}

Teresa Keico NAGASSE-SUgAhARA(1), Jonas José KISIELIUS(1), Marli UEDA-ITO(1), Suely Pires CURTI(1), Cristina Adelaide FIGUEIREDO(1), Áurea Silveira CRUZ(1), Maysa Madalena J. SILVA(2), Carmen Helena RAMOS(2), Maria Claudia C. SILVA(3), Tiyo SAKURAI(1) \& Luis Florêncio SALLES-GOMES(1)

\section{SUMMARY}

Since October 2001, the Adolfo Lutz Institute has been receiving vesicular fluids and scab specimens of patients from Paraíba Valley region in the São Paulo and Minas Gerais States and from São Patricio Valley, in the Goiás State. Epidemiological data suggested that the outbreaks were caused by Cowpox virus or Vaccinia virus. Most of the patients are dairy milkers that had vesiculo-pustular lesions on the hands, arms, forearms, and some of them, on the face. Virus particles with orthopoxvirus morphology were detected by direct electron microscopy (DEM) in samples of $49(66.21 \%)$ patients of a total of 74 analyzed. Viruses were isolated in Vero cell culture and on chorioallantoic membrane (CAM) of embryonated chicken eggs. Among 21 samples submitted to PCR using primers for hemagglutinin (HA) gene, 19 were positive. Restriction digestion with TaqI resulted in four characteristic Vaccinia virus fragments. HA nucleotide sequences showed $99.9 \%$ similarity with Cantagalo virus, described as a strain of Vaccinia virus. The only difference observed was the substitution of one nucleotide in the position 616 leading to change in one amino acid of the protein in the position 206. The phylogenetic analysis showed that the isolates clustered together with Cantagalo virus, other Vaccinia strains and Rabbitpox virus.

KEYWORDS: Vaccinia-like virus; Outbreak; Diagnosis; Electron microscopy; Virus isolation; PCR; Sequencing; Phylogenetic analysis.

\section{INTRODUCTION}

Poxviruses, measuring about 200-350 x 115-260 nm, are the largest known viruses being on the limit of the optical microscopy resolution. They present complex capsid symmetry and cores containing nucleic acids, surrounded by multiple membranes originating brick-shaped or oval forms. Two morphologic forms are described by negative staining electron microscopy, the "M" form that presents rough surface similar to the mulberry and the "C" one, with a capsule and smooth surface". They comprise a large family of linear double-stranded DNA viruses of approximately $200 \mathrm{kbp}$ and the replication takes place in the host cell cytoplasm, which is different from other DNA viruses where replication occurs inside the cell nucleus ${ }^{9,23}$.

The genus Orthopoxvirus belongs to the sub-family Chordopoxvirinae, some of which being pathogens of human and veterinary importance, causing zoonosis of impact to the public health and local economic impairment ${ }^{45}$. The main orthopoxviruses that infect humans are: the already eradicated Variola virus; Monkeypox virus, responsible for a recent outbreak in the USA ${ }^{26}$; Cowpox virus, described in Europe $e^{4,11,18}$ and Vaccinia, a virus of uncertain origin reported as the causal agent of outbreaks in India ${ }^{4,11,18}$, and which was used in the vaccination campaign for smallpox eradication. The Cowpox virus and Vaccinia virus cause a similar, localized lesion in humans when in contact with infected cow udders ${ }^{33,45}$.

The classic diagnosis for Orthopoxvirus was accomplished by virus isolation on chorioallantoic membrane (CAM) of embryonated chicken eggs and in susceptible cell cultures, detection of virus particles by electron microscopy using negative staining method and by serological methods ${ }^{24}$.

Virus identification on CAM is done by observation of characteristic lesions (pocks) produced on it. Direct electron microscopy (DEM) is the quickest method available for viral diagnosis as the virus particles

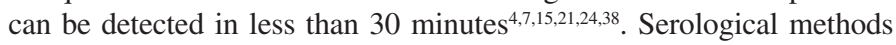
as neutralization and hemagglutination inhibition tests can also be used $^{24}$. Currently, molecular biology techniques such as the polymerase chain reaction $(\mathrm{PCR})$, restriction fragment length polymorphism (RFLP) and sequencing of viral genome are the chosen methods for the identification and characterization of these viruses $8,16,19,25,28$.

From October 2001 to January 2003 the Adolfo Lutz Institute (São Paulo, Brazil) received specimens of vesicular fluids and scabs from

(1) Instituto Adolfo Lutz, Laboratório de Biologia Molecular, Seção de Microscopia Eletrônica, Seção de Vírus Produtores de Exantemas, Seção de Culturas Celulares, Av. Dr. Arnaldo 355, 01246-902 São Paulo, SP, Brazil.

(2) Laboratório de Saúde Pública/LACEN, GO, Brazil.

(3) Vigilância Epidemiológica, Taubaté, SP, Brazil.

Correspondence to: Marli Ueda-Ito, Instituto Adolfo Lutz, Seção de Microscopia Eletrônica, Av. Dr. Arnaldo 355, 01246-902 São Paulo, SP, Brazil. E-mails: ueda@ial.sp.gov.br and marliueda@hotmail.com 
NAGASSE-SUGAHARA, T.K.; KISIELIUS, J.J.; UEDA-ITO, M.; CURTI, S.P.; FIGUEIREDO, C.A.; CRUZ, A.S.; SILVA, M.M.J.; RAMOS, C.H.; SILVA, M.C.C.; SAKURAI, T. \& SALLESGOMES, L.F. - Human vaccinia-like virus outbreaks in São Paulo and Goiás States, Brazil: virus detection, isolation and identification. Rev. Inst. Med. trop. S. Paulo, 46(6):315-322, 2004.

patients with clinical suspicion of "vesicular stomatitis" or "bovine variola". These patients were from the rural area of Paraíba Valley counties, at the East side of São Paulo State. Most of them were dairy milkers that presented lesions with vesiculo-pustular aspect on the hands, arms, forearms and some of them, in the face. In May 2003, we received the same kind of samples from São Patricio Valley, central area of Goiás State.

Our objective is to report human outbreaks caused by a Vaccinialike virus occurring in different regions of Brazil. After virus detection by DEM, we have isolated the virus on CAM of embryonated chicken eggs and in Vero cell culture, and identified it by molecular biology techniques. We emphasize the necessity of keeping our skillness in applying the old classical methodology for viral diagnosis together with the new advanced molecular techniques so as to be able to identifying the new emergent and reemergent viral agents.

\section{MATERIAL AND METHODS}

1. Patients and biological specimens: Specimens of vesicular fluids and skin lesion crusts of 74 patients were received from October 2001 to July 2003. Sixty-eight (92\%) were from 10 counties of Paraíba Valley in São Paulo State; two $(2.7 \%)$ from Minas Gerais State and four (5.4\%) from São Patricio Valley, Goiás State (Table 1). The health authorities of Goiás State had notified 18 cases, but samples of only four patients had been sent to us. The distance between the two localities is approximately $1,200 \mathrm{~km}$. The conditions of the collection, storage and consignment of the specimens to the laboratory were not in agreement with the required norms for viral diagnosis. Glass slides with smears of vesicular fluids and scabs were received without refrigeration, wrapped up in aluminum foil. The number of samples varied from one to three per patient. Samples received in triplicate were also submitted for molecular biology tests and virus isolation. Thus, for molecular characterization, 21 smear samples from different counties were processed and, to evaluate some biological aspects, 12 samples were inoculated on CAM of embryonated chicken eggs and in culture cells.

2. Direct electron microscopy (DEM): The original biological specimens were resuspended in $50 \mu \mathrm{L}$ of phosphate-buffered saline (PBS) $\mathrm{pH}$ 7.2. One drop of the suspension was put on EM grid and submitted to negative staining technique ${ }^{6}$ with $2 \%$ potassium phosphotungstate (PTK) pH 6.4. The grids were examined and the viruses were documented in a Philips EM400-T electron microscope operating in $80 \mathrm{kV}$. All 74 patients had samples examined by EM.

\section{Virus isolation}

3.1 Embryonated chicken eggs: Before inoculation into embryonated eggs and cell culture, 12 samples were each resuspended in $500 \mu \mathrm{L} 0.01 \mathrm{M}$ PBS pH 7.2 containing penicillin (500U) and streptomycin $(500 \mu \mathrm{g} / \mathrm{mL})$ (Sigma, St. Louis, USA). The suspensions, diluted to $1: 5$ and 1:15 in PBS containing antibiotics were inoculated on 10-12 days CAM of embryonated chicken eggs. The embryos were candled and the inoculation site was marked with a pencil. Each egg was inoculated with $200 \mu \mathrm{L}$ of each dilution directly into the CAM using a disposable tuberculin syringe. The inoculated eggs were incubated at $37{ }^{\circ} \mathrm{C}$ for 72 hours ${ }^{24}$.

3.2 Cell culture: The same initial viral suspensions used on embryonated chicken eggs were inoculated in cell culture. Vero cells (ATCC CCL-81) in culture tubes containing $2 \times 10^{5}$ cells $/ \mathrm{mL}$ were grown in medium 199 and $0.1 \mathrm{mM}$ non-essential amino acids, supplemented with $10 \%$ inactive fetal calf serum (FCS). The confluent cells were inoculated with $200 \mu \mathrm{L}$ of each sample suspension. After one hour at room temperature, $1 \mathrm{~mL}$ of medium with $2 \%$ FCS was added to each inoculated tube and they were incubated at $37^{\circ} \mathrm{C}$. The medium was replaced every three days. Cell cultures were observed for CPE daily during seven days. The cells with CPE were washed with PBS, fixed in situ with $1 \%$ glutaraldehyde in

Table 1

Results of EM, PCR and virus isolation in cell culture and on CAM, according to the localities of the received samples

\begin{tabular}{|c|c|c|c|c|}
\hline \multirow[t]{2}{*}{ County - Region - State (number of cases) } & \multicolumn{4}{|c|}{ Positive / Number of samples tested } \\
\hline & EM & PCR & Cell culture & CAM \\
\hline Areias - Paraíba Valley - SP (03) & $1 / 3$ & NT & NT & NT \\
\hline Cachoeira Paulista - Paraíba Valley - SP (06) & $6 / 6$ & $3 / 3$ & $1 / 1$ & $1 / 1$ \\
\hline Canas - Paraíba Valley - SP (05) & $3 / 5$ & NT & NT & NT \\
\hline Cruzeiro - Paraíba Valley - SP (05) & $3 / 5$ & NT & NT & NT \\
\hline Guaratinguetá - Paraíba Valley - SP (03) & $2 / 3$ & $1 / 1$ & $1 / 1$ & $1 / 1$ \\
\hline Lagoinha - Paraíba Valley - SP (16) & $8 / 16$ & $3 / 4$ & $2 / 2$ & $2 / 2$ \\
\hline Lavrinhas - Paraíba Valley - SP (03) & $2 / 3$ & NT & NT & NT \\
\hline Lorena - Paraíba Valley - SP (01) & $0 / 1$ & $1 / 1$ & $1 / 1$ & $1 / 1$ \\
\hline Piquete - Paraíba Valley - SP (02) & $2 / 2$ & $1 / 2$ & $1 / 1$ & $1 / 1$ \\
\hline Silveiras - Paraíba Valley - SP (24) & $18 / 24$ & $7 / 7$ & $3 / 3$ & $3 / 3$ \\
\hline Delfim Moreira - Paraíba Valley - MG (01) & $0 / 1$ & NT & NT & NT \\
\hline Juiz de Fora - MG (01) & $0 / 1$ & NT & NT & NT \\
\hline Rianópolis - São Patricio Valley - GO (03) & $3 / 3$ & $2 / 2$ & $2 / 2$ & $2 / 2$ \\
\hline Morro Agudo - São Patricio Valley - GO (01) & $1 / 1$ & $1 / 1$ & $1 / 1$ & $1 / 1$ \\
\hline Total & $49 / 74$ & $19 / 21$ & $12 / 12$ & $12 / 12$ \\
\hline
\end{tabular}

NT $=$ not tested 
NAGASSE-SUGAHARA, T.K.; KISIELIUS, J.J.; UEDA-ITO, M.; CURTI, S.P.; FIGUEIREDO, C.A.; CRUZ, A.S.; SILVA, M.M.J.; RAMOS, C.H.; SILVA, M.C.C.; SAKURAI, T. \& SALLESGOMES, L.F. - Human vaccinia-like virus outbreaks in São Paulo and Goiás States, Brazil: virus detection, isolation and identification. Rev. Inst. Med. trop. S. Paulo, 46(6):315-322, 2004.

$0.15 \mathrm{M}$ PBS $\mathrm{pH} 7.2$ for one hour at $4{ }^{\circ} \mathrm{C}$. After being rinsed twice with cacodylate buffer and stained directly with toluidine blue the cells were examined by light microscopy and photographed ${ }^{24}$.

4. Molecular biology techniques: The molecular biology techniques (PCR, sequencing, RFLP, similarity determination of the sequences and phylogenetic analyses) had the purpose of identifying the virus detected by EM.

4.1 Viral DNA extraction: Viral DNA was obtained directly from 21 smears samples, one Vero cell culture isolate and one positive control sample (Vac - lst - strain Elstree - Liverpool - UK) using a modified protocol described by ROPP et al. ${ }^{28}$. Briefly, the digested DNA was extracted twice with phenol-chloroform-isoamyl alcohol solution (25:24:1) (Sigma, St. Louis, MO), precipitated with isopropanol, washed with $70 \%$ ethanol, air dried and dissolved in $50 \mu \mathrm{L}$ of milliQ water.

4.2 Primers: The primers EACP1 (ATGACACGATTGCCAATAC) and EACP2 (CTAGACTTTGTTTTCTG) described by ROPP et al. ${ }^{28}$ were used to amplify HA gene of Eurasia-African subgroup of the genus Orthopoxvirus, producing amplicons of $927 \mathrm{bp}$. We also used the set of primers HAOUTF (CCAAATATATTCCCATAGTC), HAOUTR (GACATAATACTATCTGGATC), HAINTF (GACATAATACTATCTGGATC) and HAINTR (GTGGATTCTTCAGATGATGC), described by DAMASO et al. ${ }^{8}$. The primers HAOUTF and HAOUTR flank the open reading frame of the HA gene amplifying a product of 1180 bp which includes the 927 nucleotides of the HA gene. The pair of primers HAINTF and HAINTR, which anneal in the mid-region of the HA coding sequence, was used in the sequencing reaction to provide overlapping sequences.

4.3 Polymerase chain reaction (PCR): PCR in a total volume of $100 \mu \mathrm{L}$ was performed in the following conditions: $5 \mu \mathrm{L}$ of the DNA sample; 25 pmol of each primer; $20 \mathrm{mM}$ tris- $\mathrm{HCl}(\mathrm{pH} 8.4) ; 50 \mathrm{mM}$ $\mathrm{KCl} ; 1.5 \mathrm{mM} \mathrm{MgCl} ; 0.25 \mathrm{mM}$ of each dNTPs; $2 \mathrm{U}$ Taq DNA polymerase (Invitrogen, Carlsbad, CA). The used program started with a denaturation step at $94{ }^{\circ} \mathrm{C}$ for two min. Then, 35 times through denaturation at $94{ }^{\circ} \mathrm{C}$ for one min, annealing at $50{ }^{\circ} \mathrm{C}$ for one min and polymerization at $72{ }^{\circ} \mathrm{C}$ for one min, ending with a step at $72{ }^{\circ} \mathrm{C}$ for five min, using a 2400 Perkin Elmer Cetus thermal cycler. The same PCR reagents and protocol were used to the set of primers EACP1/ EACP2 and HAOUTF/HAOUTR.

PCR products were identified by electrophoresis in $1 \%$ agarose gel containing $0.5 \mu \mathrm{g} / \mathrm{mL}$ ethidium bromide (Sigma, St. Louis, MO) in $40 \mathrm{mM}$ tris-acetate and $1 \mathrm{mM}$ EDTA buffer (TAE) (Sigma, St. Louis, $\mathrm{MO})^{31}$.

4.4 Restriction fragment length polymorphism (RFLP): Restriction digestions were done adding 5U of TaqI (MBI Fermentas, Hanover, MD) in $30 \mu \mathrm{L}$ of DNA amplified with EACP1/EACP2 primers and incubated at $65^{\circ} \mathrm{C}$ for two hours. DNA products were fractionated by gel electrophoresis in $2 \%$ agarose gel in TAE buffer ${ }^{28}$.

4.5 HA gene sequencing: Twelve PCR amplified samples from seven different counties (Cachoeira Paulista, Guaratinguetá, Lagoinha, Lorena, Piquete, Silveiras and Rianópolis) were sequenced.
The amplicons were purified with the commercial kit "Concert rapid PCR extraction system" (GIBCO/BRL, Carlsbad, CA) following the procedure described by the manufacturer. About $20 \mathrm{ng}$ of the purified amplicon were sequenced with four primers (HAOUTF, HAOUTR, HAINTF and HAINTR) using the kit "BIGDYE Terminator Cycle Sequencing" (Foster City, CA). An automated DNA sequencer, model 377 ABI PRISM, Applied Biosystems, Inc. was used.

The obtained sequences were edited in the Sequence Navigator 1.0 program (Applied Biosystems, Foster City, CA). The comparative analyses of the DNA sequences were based on nucleotide and amino acid aligned sequences using CLUSTAL X software ${ }^{37}$. The phylogenetic tree, based on aligned nucleotides, was constructed, applying the neighbor-joining method with calculated bootstrap confidence intervals of 1000 heuristic search replicate, using MEGA, version 2.1 (Molecular Evolutionary Genetics Analyses, Pennsylvania State University). Genetic distance was determined by proportional distance method, Kimura two parameter model, applying pairwise deletion of gaps and equally weighting both transition and transversion for all three codon positions.

To determine the similarity among the $12 \mathrm{HA}$ gene nucleotide sequences and the Cantagalo virus it was used the module MegAlign 4.00 of the program DNASTAR (software Lasergene).

\section{RESULTS}

1. Patients: Sixty-six patients were male, eight female and the age ranged from 12 to 78 years old (Fig. 1). Paraíba Valley region has in the milk production and dairy products, one of its main economic activities. The majority of the patients were dairymaids, milkmen and some were farmers and their relatives. São Patricio Valley comprises many farms of vast extension dedicated to beef cattle production. As clinical characteristic, they presented skin lesions in the form of vesicles with festering secretion, mainly on the hands, fingers, arms and on the face. Other clinical symptoms were fever, sweat, headache, appetite loss, erythema, pains in the body, itches in the lesion and increased axillary ganglions. Three patients had to be taken into hospital because they developed more serious symptoms.

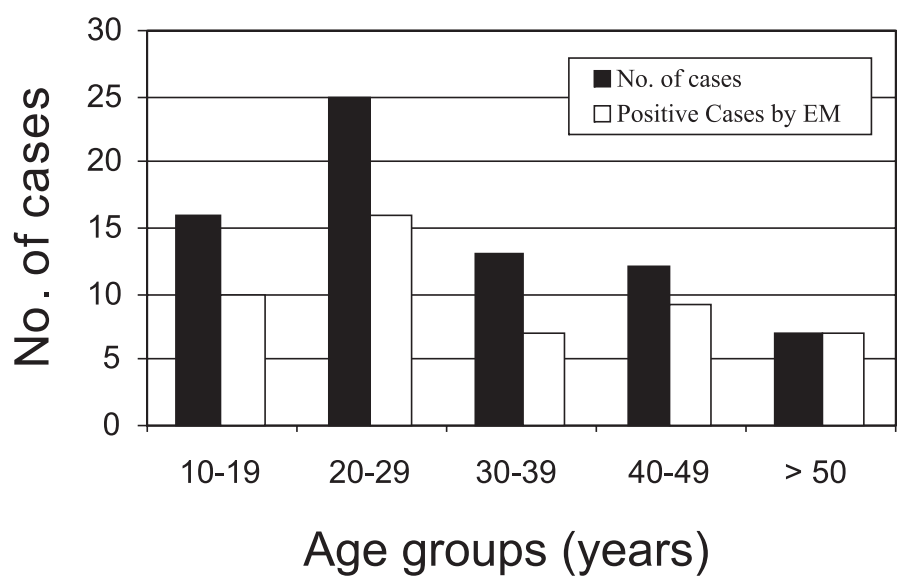

Fig. 1 - Number of cases and positive cases by EM according to age range. 
2. Electron microscopy: Virus particles with characteristic morphology of orthopoxvirus (Fig. 2) were detected in $66.21 \%$ (49/74) of the examined samples. Out of 49 positive samples, 45 (91.8\%) were from patients of Paraíba Valley-SP and four (8.2\%) of São Patricio-GO. The two samples from Minas Gerais State were negative (Table 1). The viruses had brick-shaped form, measuring about $310 \times 245 \mathrm{~nm}$ (Fig. 2) with dumbbell-shaped core. Most of virus presented " $M$ " form morphology, with rough surface formed by filaments (Fig. 2a). Morphology of "C" form particles was also observed, however in smaller number (Fig. 2b). Isolated viral particles were predominant but some small agglomerates were also observed (Figs. 2c and 2d). About $70 \%$ of the positive samples presented a great number of viral particles.

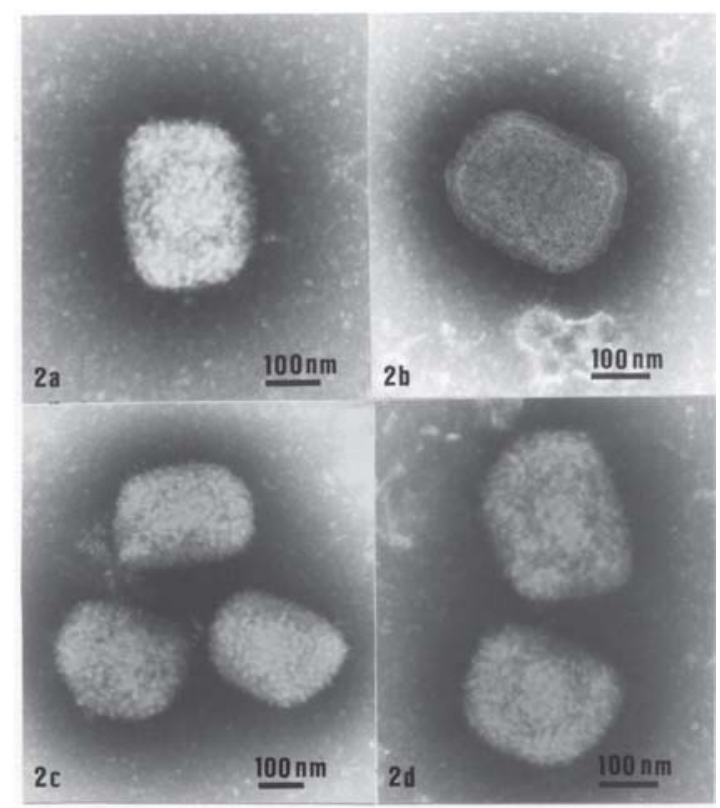

Fig. 2 - Orthopoxvirus particles with characteristic morphology detected by direct electron microscopy: $2 \mathrm{a}-\mathrm{M}$ form covered by filamentous; $2 \mathrm{~b}-\mathrm{C}$ capsular form; $2 \mathrm{c}$ and $2 \mathrm{~d}$ - small cluster of Orthopoxvirus particles.

\section{Virus isolation}

3.1 CAM of embryonated chicken eggs: All the 12 samples inoculated on CAM of embryonated chicken eggs resulted positives. The viruses growth on CAM produced large pocks with 3 to $4 \mathrm{~mm}$ diameter, central necrosis and ulcerations with slightly hemorrhagic appearance (Fig. 3c). The presence of the virus in these pocks was confirmed by EM.

3.2 Cell culture: The 12 samples inoculated in cell culture were also positives (Table 1). The first alterations in infected cells were observed 24 hours post-inoculation, consisting in increased refractability and rounding cells. After seven days, cytophatic effects (CPE) consisting of multinucleated cell plaques with extensive degeneration was observed (Figs. 3a e 3b).

On the second passage, CPE became detectable on the second day. Orthopoxvirus particles were detected by EM in the second passage of the cell culture sediment and confirmed by PCR.

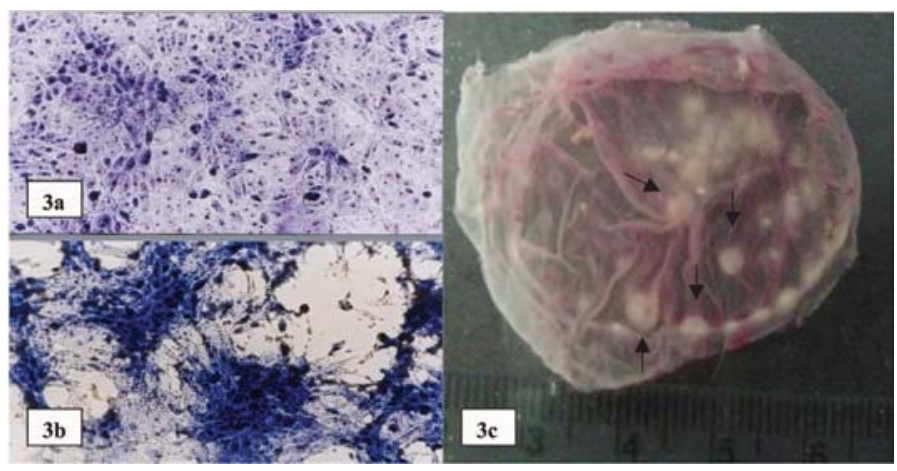

Fig. 3 - Stained monolayers of normal (3a) and Orthopoxvirus infected (3b) Vero cells, $\mathrm{CAM}$ of embryonated chicken eggs inoculated with specimen of patient (3c). Arrows indicate characteristic vaccinia pocks.

\section{Analyses by molecular biology techniques}

4.1 PCR amplification: PCR with EACP1 and EACP2 primers produced an amplicon of $927 \mathrm{bp}$, in agreement with the results obtained by ROPP et al. ${ }^{28}$. The primers HAOUTF and HAOUTR, described by DAMASO et $_{\text {al. }}{ }^{8}$, amplified a product of $1180 \mathrm{bp}$, compatible with the expected for Orthopoxvirus. The Fig. 4 shows PCR results of one sample (Silveiras-2382) and the positive control (Vac - 1st - Elstree - Liverpool - UK) with the two sets of primers. During the standardization phase of PCR, the DAMASO's primers resulted in better yield of amplification. Therefore, we decided to use these primers for all PCRs (21 patient samples, 1 Vero cell culture isolate and positive control), except for RFLP, where it was used ROPP's primers. Of the 21 samples submitted to PCR, 19 were positive. The Vero cell culture isolate was also positive.

4.2 Sequencing: The result of the HA nucleotides alignment of the 12 samples and the Cantagalo virus indicates a similarity of $99.9 \%$

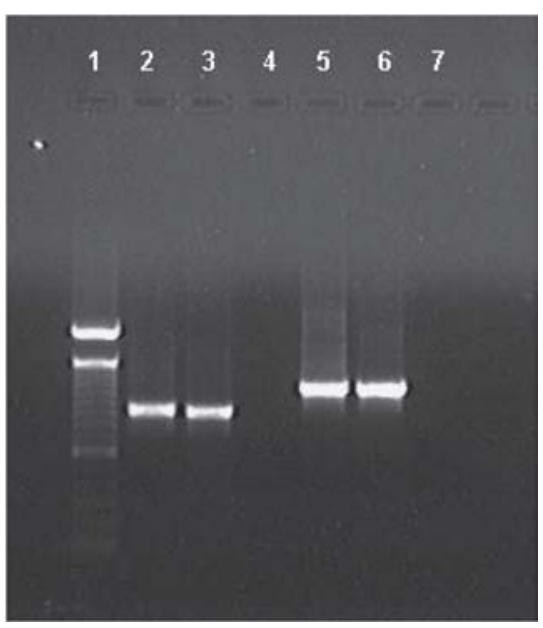

Fig. 4 - Agarose gel electrophoresis of HA gene PCR. Lanes: (1) DNA size marker 100bp ladder (Invitrogen, Carlsbad, CA); (2) Positive control - Vaccinia Virus - 1st - strain Elstree (Liverpool, UK) amplified with EACP1/EACP2, 927 bp; (3) Sample 2382 amplified with EACP1/EACP2, 927 bp; (4) Negative control with EACP1/EACP2; (5) Positive control Vaccinia Virus - 1st - strain Elstree (Liverpool, UK) amplified with HAOUTF/HAOUTR, 1180 bp; (6) Sample 2382 amplified with HAOUTF/HAOUTR, 1180 bp; (7) Negative control with HAOUTF/HAOUTR. 
NAGASSE-SUGAHARA, T.K.; KISIELIUS, J.J.; UEDA-ITO, M.; CURTI, S.P.; FIGUEIREDO, C.A.; CRUZ, A.S.; SILVA, M.M.J.; RAMOS, C.H.; SILVA, M.C.C.; SAKURAI, T. \& SALLESGOMES, L.F. - Human vaccinia-like virus outbreaks in São Paulo and Goiás States, Brazil: virus detection, isolation and identification. Rev. Inst. Med. trop. S. Paulo, 46(6):315-322, 2004.

between them. The only difference was the change of nucleotide A to $\mathrm{G}$ in the position 616 of HA gene (Fig. 5a), resulting in substitution of the amino acid Lysine-K (basic character) for the glutamic acid-E (acid character) in the position 206 (Fig. 5b). As the 12 sequenced samples were identicals, one of them (Goiás 2549) was selected to represent the group (Figs. 5a e 5b).

4.3 RFLP: The RFLP of the amplified 927 bp products of the HA gene resulted in four fragments $(451,295,105$ and $97 \mathrm{bp})$ as expected, and in agreement with the results obtained by ROPP et al..$^{28}$ (data not shown). Moreover, the nucleotides sequencing analysis of the amplicon confirmed the presence of $3 \mathrm{Taq}$ I restriction sites (Fig. 5a).

4.4 Phylogenetic analysis: The phylogenetic analysis of the HA gene shows that our samples, represented by one of each county, clustered together with Cantagalo, Rabbitpox and Vaccinia virus (Fig. 6).

\section{DISCUSSION}

Since smallpox eradication in the end of the 70 s, reports on outbreaks of human infections by Poxvirus have been rare ${ }^{33}$. Different viruses such as Cowpox virus and Vaccinia virus (genus Orthopoxvirus); Orf, Bovine Papular Stomatitis and Pseudocowpox (genus Parapoxvirus); and Bovine Herpes 2 (Herpesvirus) can cause very similar lesions in cow udders and in dairymaid hands and arms $\mathrm{s}^{4,45}$. The etiological diagnosis of these diseases, commonly known as "disease of dairymaid", "bovine variola", "pseudovariola" or still "paravaccinia" is difficult to be established correctly. According to WEIBLEN ${ }^{45}$, cases clinically diagnosed as "pseudovariola" are not always confirmed at the laboratory as Parapoxvirus. Outbreaks initially attributed to Cowpox virus were later on confirmed to be caused by Vaccinia virus ${ }^{11}$. In our case, the available clinical and epidemiological data, plus the EM results, have suggested that a Vaccinia-like virus or even a Cowpoxlike virus not yet described in our country was the pathogen associated with these outbreaks.

Although it is not possible to distinguish the species of the genus Orthopoxvirus, DEM is the easiest and quickest laboratory diagnostic method available to differentiate morphologically these viruses from Parapoxvirus and Herpesviridae, making this technique an important a) $\mathrm{Cg}$ virus Goias 2549 $\mathrm{Cg}$ virus Goias 2549

Cg virus Goias2549

$\mathrm{Cg}$ virus Goias2549

$\mathrm{Cg}$ virus Goias 2549

$\mathrm{Cg}$ virus Goias2549

$\mathrm{Cg}$ virus Goias2549

Cg virus Goias2549

$\mathrm{Cg}$ virus Goias 2549

$\mathrm{Cg}$ virus Goias2549

Cg virus Goias 2549

Cg virus

b) Cg virus Goias2549

Cg virus Goias 2549

Cg virus Goias2549

$\mathrm{Cg}$ virus Goias2549
ATG ACA CGA TTA CCA ATA CTT TTG TTA CTA ATA TCA TTA GTA TAC GCT ACA CTT TCT CTT CAg ACA TCT AAA AAA ATA

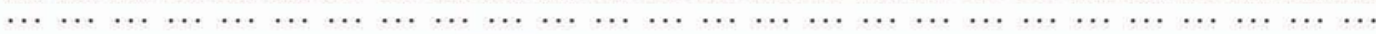
GGT GAT GAT GCA ACT CTA TCA TGT AAT CGA AAT AAT ACA AAT GAC TAC GTT GTT ATG AGT GCT TGG TAT AAG GAG CCC

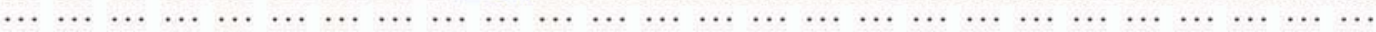
AAT TCC ATT ATT CTT TTA GCT GCT AAA AGC GAC GTC TTG TAT TTT GAT AAT TAT ACC AAG GAT AAA ATA TCT TAC GAC

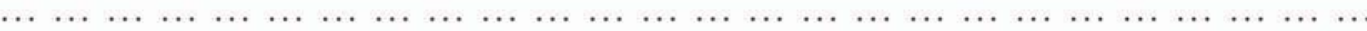
TCT CCA TAC GAT GAT CTA GTT ACA ACT ATC ACA ATT AAA TCA TTG ACT GCT AGA GAT GCC GGT ACT TAT GTA TGT GCA $\begin{array}{lllllllllllllllllllllllllllllll}\cdots & \ldots & \ldots & \ldots & \ldots & \ldots & \ldots & \ldots & \ldots & \ldots & \ldots & \ldots & \ldots & \ldots & \ldots & \ldots & \ldots & \ldots & \ldots & \ldots & \ldots & \ldots & \ldots & \ldots & \ldots & \ldots\end{array}$ TTC TTT ATG ACA TCG CCT ACA AAT GAC ACT GAT AAA GTA GAT TAT GAA GAA TAC TCC ACA GAG TTG ATT GTA AAT ACA

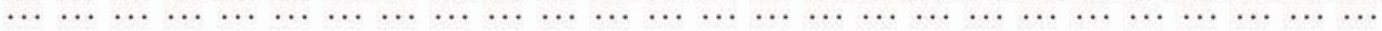
GAT AGT GAA TCG ACT ATA GAC ATA ATA CTA TCT GGA TCT ACA CAT TCA CCG GAA ACT AGT TCT GAg AAA CCA GAG GAT

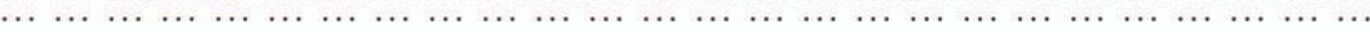
AtA GAT AAT TTT AAT TGC TCG TCG GTA ITC GA ATC GCG ACT CCG GAA CCA ATT ACT GAT AAT GTA GAA GAT CAT ACA

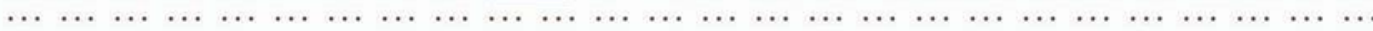
GAC ACC GTC ACA TAC ACT AGT GAT AGC ATT AAT ACA GTA AGT GCA TCA TCT GAA GAA TCC ACA ACA GAC AAG ACT CCG

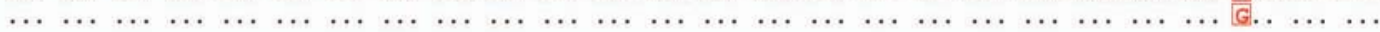
GAA CCA ATT ACT GAT AAA GAA GAT CAT ACA GTT ACA GAC ACT GTC TCA TAC ACT ACA GTA AGT ACA TCA TCT GGA ATT

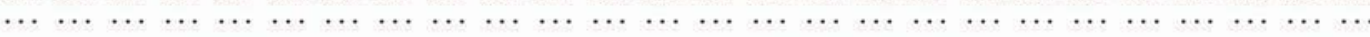
GTC ACT ACT AAA TTA ACC ACC GAT GAT GCG GAT CTT TAT GAT ACA GTA CCA CCA ACT ACT GTA GGC GGT AGT ACA ACC

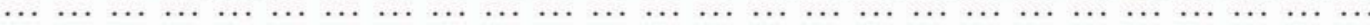
TCT ATT AGC AAT TAT AAA ACC AAG GAC TTT GTA GAA ATA TTT GGT ATT ACC GCA TTA ATT ATA TTG TCG GCC GTG GCA

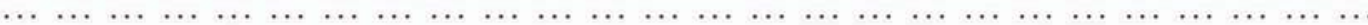

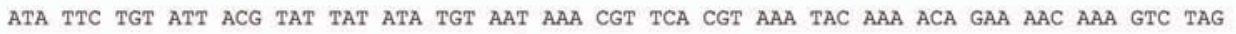

MTRLPILLLL ISLVYATLSL QTSKKIGDDA TLSCNRNNTN DYVVMSAWYK EPNSIILLAA KSDVLYFDNY TKDKISYDSP YDDLVTTITI KSLTARDAGT YVCAFFMTSP TNDTDKVDYE EYSTELIVNT DSESTIDIIL SGSTHSPETS SEKPEDIDNF

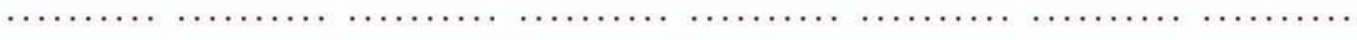
NCSSVFEIAT PEPITDNVED HTDTVTYTSD SINTVSASSE ESTTDKTPEP ITDKEDHTVT DTVSYTTVST SSGIVTTKLT

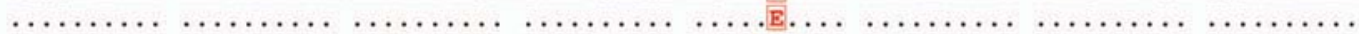

TDDADLYDTV PPTTVGGSTT SISNYKTKDF VEIFGITALI ILSAVAIFCI TYYICNKRSR KYKTENKV

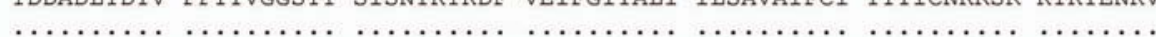

Fig. 5 - Comparative HA gene sequence alignment of an isolated virus (Goiás 2549) and Cantagalo virus. The boxed areas represent TaqI restriction sites in blue, and distinct nucleotides (5a) and amino acids $(5 \mathrm{~b})$ in red. 


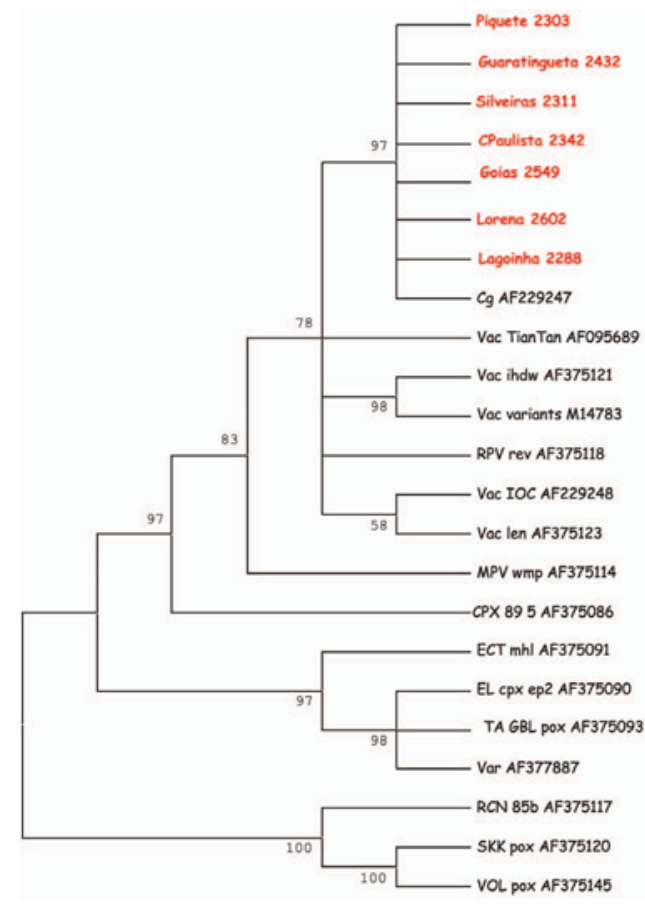

Fig. 6 - Phylogenetic tree constructed by the neighbor-joining method of MEGA based on HA gene nucleotides of Brazilian Vaccinia-like isolates from 7 different localities and other Orthopoxviruses. Each number at nodes is the percentage of 1000 bootstrap replicate support. Our isolates are named with the locality and the strain. The names of the viruses are abbreviated, followed by the strain and the GenBank accession number: Cantagalo $(\mathrm{Cg})$, Vaccinia (Vac), Rabbitpox (RPV), Cowpox (CPX), Ectromelia (Ect), Elephantpox (El), Tatera gerbilpox (TA), Variola (Var), Raccoonpox (RCN), Skunkpox (SKK), Volepox (VOL).

aid in the viral diagnosis ${ }^{4,15,38}$. In a comparative study on Variola virus detection techniques, SALLES-GOMES et al. ${ }^{30}$ observed an agreement of $89 \%$ between the transmission electron microscopy and the virus isolation on CAM of embryonated chicken eggs. Our finding of $66.21 \%$ positive cases is probably underestimated due to the poor quality of the specimens received for viral diagnosis. Most of the negative samples were those of scabs or smears of secretions collected during the cicatrization phase of the lesion. The ideal sample for EM analysis is the one collected from blisters since many virus particles are found in its liquid content. It is also probable that viral particles could not be detected in many samples due to the degeneration of virus subsequent to bad specimen storage condition and to the lapse of time between its collection and arrival at the laboratory, and even due to the insufficient number of particles in the analyzed samples. The specimens were not properly collected for viral diagnosis and they were shipped to the laboratory without refrigeration, some days after the collection. In spite of these conditions, we have succeeded in isolating the virus in Vero cell culture (Figs. 3a and 3b) and on CAM of embryonated chicken eggs (Fig. 3c), confirming that Poxviruses, differently from most of the viruses, are highly resistant to adverse environmental conditions during transport, handling and storage ${ }^{24}$.

The macroscopic aspects of the pocks produced on CAM were large, white, with a small haemorrhagic point in the middle of some pocks and a slight general diffuse haemorrhage over the membrane (Fig. 3c). According to FENNER ${ }^{10}$, this macroscopic aspect does not allow the differentiation between Vaccinia virus and Cowpox virus, because both of them, depending on the strain, can produce the same lesion feature on CAM. The exanthematic virus characterization on CAM was very used decades ago, mainly during the Smallpox Eradication Campaign, when the differential diagnosis among Smallpox, Chickenpox (it does not grow) and Herpesvirus group was routinely done ${ }^{24}$.

In spite of we could not have sequenced all samples, the analyzed group can be considered representative because possess samples of all affected areas. The sequencing and profile analyses after digestion with TaqI of the 927 bp PCR product of samples from counties of São Paulo and Goiás States, showed that the isolates were Vaccinia-like, similar to the Cantagalo virus ${ }^{8}$. The distinction between Vaccinia virus and Cowpox virus can be done easily with the restriction enzyme TaqI which recognize the palindrome TCGA of the gene HA, generating four fragments in the case of Vaccinia virus and six in the Cowpox $v_{i r u s^{28}}$. The sequence analyses of the amplicons revealed the presence of three restriction sites, resulting in four fragments of sizes compatible to those described by ROPP et al. ${ }^{28}$ (Fig. 5a). The nucleotides sequence of this isolated strain, compared with that of Cantagalo virus showed only one nucleotide alteration, in the position 616 (Fig. 5a), resulting in substitution of the amino acid Lysine- $\mathrm{K}$ (basic character) for the glutamic acid-E (acid character) (Fig. 5b).

The disease affected people of all age groups, with predominance in the groups below 30 years of age (Fig. 1). This is an expected result because most of dairy workers in these groups were not vaccinated against smallpox and they are the ones that have closer contact with the cattle. Most of the human infections by Cowpox virus ${ }^{4,18}$ and Monkeypox virus ${ }^{16}$ also occur in individuals below 18 years old that were not vaccinated against smallpox. Seroepidemiology studies detected a high prevalence of total and neutralizing antibodies in the population above 30 years old, which have been vaccinated against smallpox ${ }^{5,25}$. In 1979, after two years without any registration of smallpox case following the successful worldwide vaccination campaign, the WHO proclaimed that the disease had been eradicated from the World.

The great number of human cases analyzed is expressive mainly in Paraíba Valley (Table 1). We could not find any published report on outbreaks of Vaccinia virus with so many cases. It is probable that manual milking, still a very common practice in that region by small producers, the proximity of the farms and the trade facility in cattle fairs have facilitated the widespread of the virus. We have to mention that at the same occasion there was a great "bovine variola" outbreak that affected about 1,500 cattle in the same region (Paraíba Valley) 39,40,41. The other region where an outbreak occurred is São Patricio Valley, approximately 1,200 km far from Paraíba Valley (Fig. 7). Between both localities there are many small cities and geographic accidents.

Occurrences of human outbreaks caused by Vaccinia-like virus have been reported recently in several areas of our country ${ }^{8,32,36}$. The literature data show that the occurrence of human Vaccinia-like virus outbreaks is rare. Outbreaks of Bufalopox virus, another Vaccinia-like virus strain, were described only in India ${ }^{8,11}$. We agree with DAMASO et al. ${ }^{8}$ that the viruses detected in Brazil could be also a new Vaccinia-like virus strain, epidemiologically similar to the Bufalopox virus. It is not known how long these viruses circulated in Brazil; there are reports on "bovine variola" or "vaccinia" occurrences in humans, since 


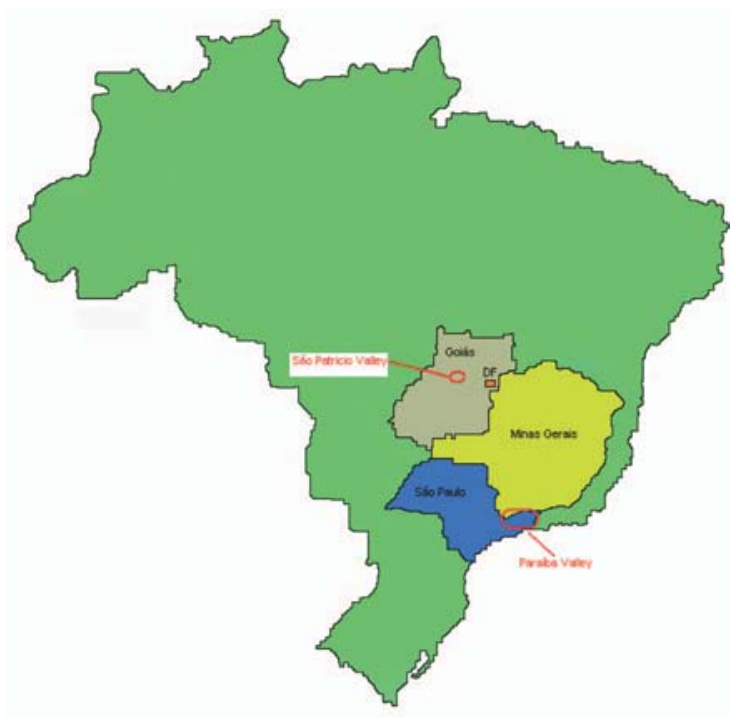

Fig. 7 - Localities in São Paulo and Goiás States where the two human Vaccinia-like outbreaks occurred. The red circle indicates São Patricio and Paraíba Valleys distant one from the other approximately $1,200 \mathrm{Km}$.

$1910^{1,2,3,14,22,27,29,34,35,42,43,44}$. There are several old papers that describe outbreaks with clinical and epidemiological characteristics similar to those that are occurring now. It is important to mention that many of those outbreaks were found in the same region where the cases now reported occurred.

Two strains of Poxvirus, SPAn-232 and BeAn-58058, isolated in Brazil in the 1960s, have been characterized only recently by molecular biology techniques. The virus SPAn-232, isolated from a sentinel mouse in the rural area of Cotia-SP ${ }^{17,20}$, was characterized as a Vaccinia-like virus $^{13}$ and, maybe, it could have some relation to all Vaccinia-like viruses that now are being detected in our country. Even though the vector of that virus is not known, the fact that the virus has been isolated from a sentinel mouse, suggests that it could be an arthropod ${ }^{13}$. The BeAn58058, isolated from wild rodents in surrounding areas of Belém-PA, also presents molecular aspects similar to the Vaccinia-like virus ${ }^{12}$. The comparison of sequences of these two viruses with the recent isolates could explain many epidemic aspects. The accomplishment of a seroepidemiologic study would also be important to evaluate the prevalence of specific antibodies in the population. The antibody levels in human population, in cattle and in wild animals would bring important informations about the mechanisms of infection by those viruses, as well as would allow the evaluation of the population's protection level against Variola virus, which underwent bioengineering treatment to become a powerful bioweapon against human population.

The endemic character of this disease caused by Vaccinia-like virus in some regions of Brazil seems to be established. There are few studies about Poxvirus in Brazil and with this report is intended to point the need of improving the epidemiologic surveillance with a seropidemiologic study that would help to determine the transmission chain, as well as to identify the natural host of those viruses, once this zoonosis is detrimental to the local economy besides being a public health problem.

\section{RESUMO}

\section{Surtos de vírus Vaccinia-like nos Estados de São Paulo e Goiás, Brasil: detecção, isolamento e identificação viral}

A partir de outubro de 2001, o Instituto Adolfo Lutz tem recebido amostras de líquido vesicular e crostas de lesões de pele de pacientes das regiões do Vale do Paraíba, Estado de São Paulo e do Vale do São Patricio, Estado de Goiás. Os dados clínicos e epidemiológicos sugeriam que os surtos poderiam ser causados por Cowpox virus ou Vaccinia virus. A maioria dos pacientes era ordenhadores que tinham lesões vesicopustulares nas mãos, braços, antebraços e alguns na face. A análise por microscopia eletrônica direta (MED) detectou partículas com morfologia de vírus do gênero Orthopoxvirus em amostras de 49 $(66,21 \%)$ pacientes dos 74 analisados. Os vírus foram isolados em membrana corioalantóide (MCA) de ovo embrionado de galinha e em linhagem celular Vero com confirmação por MED e PCR. Das 21 amostras de lesões submetidas ao PCR utilizando iniciadores para o gene da hemaglutinina (HA), 19 foram positivas. A digestão por enzima de restrição TaqI resultou em quatro fragmentos característicos de Vaccinia virus. A análise nucleotídica do seqüenciamento revelou que esses vírus apresentam 99,9\% de similaridade com o Cantagalo virus, descrito como uma cepa de Vaccinia virus, havendo apenas alteração de um nucleotídeo na posição 616 com mudança de um aminoácido na proteína na posição 206. A análise filogenética mostrou que os isolados se agruparam junto aos Cantagalo virus, outras cepas de Vaccinia virus e Rabbitpox virus.

\section{ACKNOWLEDGEMENTS}

We thank Drs. Hatune Tanaka, Dalton Ramalho Weigl, Eliseu Alves Waldman, Júlia Maria Martins de Souza Felippe and Zoraida C. F. Grillo for a critical review of this paper and suggestions. We also thank Dr. João Luiz Costa Cardoso (Instituto Butantan) for kindly providing the inactivated Vaccinia virus (Vac - 1st - strain Elstree - Liverpool -UK).

\section{REFERENCES}

1. ANGULO, J.J.; FLORES, M.R. \& SALLES-GOMES, L.F. - Spread of vaccinia in dermatological infirmary. Hospital (Rio de J.), 69: 205-212, 1966.

2. ANGULO, J.J.; SALLES-GOMES, L.F.; MAGALDI-JORDÃO, F.B. \& AMOROSINO, A. - An epidemiological study of vaccinia in man. III. Subclinical infections. Hospital (Rio de J.), 72: 809-819, 1967

3. ANGULO, J.J.; SALLES-GOMES, L.F.; MAGALDI-JORDÃO, F.B.; RABELLO, S.I. \& AMOROSINO, A. - An epidemiological study of vaccinia in man. I. Effects of a mass vaccination in a pemphigus foliaceus. Hospital (Rio de J.), 72: 791-799, 1967.

4. BAXBY, D.; BENNETT, M. \& GETTY, B. - Human cowpox 1969-93: a review based on 54 cases. Brit. J. Derm., 131: 598-607, 1994.

5. BORGES, M.B.J.; KATO, S.E.M.; HONORATO, A.O. et al. - Seroepidemiological survey for vaccinia antibodies in staff members of Bio-Manguinhos/Fiocruz. In: NATIONAL MEETING OF VIROLOGY, 14, Florianópolis. Virus Rev. Res., 8 (supl. 1): 246$247,2003$.

6. BRENNER, S. \& HORNE, R.W. - A negative staining method for high resolution electron microscopy of viruses. Biochim. Biophys. Acta, 34: 103-110, 1959.

7. CRUICKSHANK, J.G.; BEDSON, H.S. \& WATSON, D.H. - Electron microscopy in the rapid diagnosis of smallpox. Lancet, 2: 527-530, 1966. 
NAGASSE-SUGAHARA, T.K.; KISIELIUS, J.J.; UEDA-ITO, M.; CURTI, S.P.; FIGUEIREDO, C.A.; CRUZ, A.S.; SILVA, M.M.J.; RAMOS, C.H.; SILVA, M.C.C.; SAKURAI, T. \& SALLESGOMES, L.F. - Human vaccinia-like virus outbreaks in São Paulo and Goiás States, Brazil: virus detection, isolation and identification. Rev. Inst. Med. trop. S. Paulo, 46(6):315-322, 2004.

8. DAMASO, C.R.; ESPOSITO, J.J.; CONDIT, R.C. \& MOUSSATCHE, N. - An emergent poxvirus from humans and cattle in Rio de Janeiro State: Cantagalo virus may derive from Brazilian smallpox vaccine. Virology, 277: 439-449, 2000.

9. DOANE, F.W. \& ANDERSON, N. - Poxviridae. In: DOANE, F.W. \& ANDERSON, N., ed. Electron microscopy in diagnostic virology. Cambridge, University Press, 1987. p. $87-95$.

10. FENNER, F. - The biological characters of several strains of vaccinia, cowpox and rabbitpox viruses. Virology, 5: 502-529, 1958.

11. FENNER, F. - Poxviruses. In: FIELDS, D.M.; KNIPE, P.M.; HOWLEY, P.M. et al., ed Virology. 3. ed. Philadelphia, Lippincott-Raven, 1996. p. 2673-2702.

12. FONSECA, F.G.; LANNA, M.C.; CAMPOS, M.A. et al. - Morphological and molecular characterization of the poxvirus BeAn 58058. Arch. Virol., 143: 1171-1186, 1998.

13. FONSECA, F.G.; TRINDADE, G.S.; SILVA, R.L.A. et al. - Characterization of a vaccinialike virus isolated in a Brazilian forest. J. gen. Virol., 83: 223-228, 2002.

14. GOMES, M.J. - Cow-pox (variola das vacas). Biológico (S. Paulo), 3: 340-342, 1937.

15. HAZELTON, P.R. \& GELDERBLOM, H.R. - Electron microscopy for rapid diagnosis of infectious agents in emergent situations. Emerg. infect. Dis., 9: 294-303, 2003.

16. HUTIN, Y.J.F.; WILLIAMS, R.J.; MALFAIT, P. et al. - Outbreak of human monkeypox, Democratic Republic of Congo, 1996 to 1997. Emerg. infect. Dis., 7: 434-438, 2001.

17. KARABATSOS, N., ed. - International catalogue of arboviruses. 3. ed. San Antonio, American Journal of Tropical Medicine and Hygiene, 1985.

18. LEVIN, N.A. \& WILSON, B.B. - Cowpox infection, human. eMedicine Journal, 2001 [http://www.emedicine.com/derm/topic87.htm]

19. LOPAREV, V.N.; MASSUNG, R.F.; ESPOSITO, J.J. \& MEYER, H. - Detection and differentiation of old world orthopoxviruses: restriction fragment length polymorphism of the crmB gene region. J. clin. Microbiol., 39: 94-100, 2001.

20. LOPES, O.S.; LACERDA, J.P.G.; FONSECA, I.E.M. et al. - Cotia virus: a new agen isolated from sentinel mice in São Paulo, Brazil. Amer. J. trop. Med. Hyg., 14: 156$157,1965$.

21. MACRAE, A.D.; FIELD, A.M.; McDONALD, J.R.; MEURISSE, E.V. \& PORTER, A A. - Laboratory differential diagnosis of vesicular skin rashes. Lancet, 2: 313-316, 1969.

22. MELLO, D.; QUEIROZ, J.C. \& TOMANIK, J.P. - Varíola bovina. Observações sobre casos animais e humanos ocorridos no Estado de São Paulo em 1959. Biológico (S. Paulo), 26: 132-136, 1960.

23. MOSS, B. - Poxviridae: the viruses and their replication. In: FIELDS, D.M.; KNIPE, P.M.; HOWLEY, P.M. et al., ed. Virology. 3. ed. Philadelphia, Lippincott-Raven, 1996. p. $2637-2671$.

24. NAKANO, J.H. - Poxviruses. In: LENETTE, E.H. \& SCHMIDT, N.J., ed. Diagnostic procedures for viral, rickettsial and chlamydial infections. 5. ed. Washington, American Public Health Association, 1979. p. 257-308.

25. PELKONEN, P.M.; TARVAINEN, K.; HYNNINEN, A. et al. - Cowpox with severe generalized eruption, Finland. Emerg. infect. Dis., 9: 1458-1461, 2003.

26. REED, K.D.; MELSKI, J.W.; GRAHAM, M.B. et al. - The detection of monkeypox in humans in the Western Hemisphere. New Engl. J. Med., 350: 342-350, 2004.

27. REIS, R.; FIGUEIREDO, J.B. \& PACHECO, M. - Varíola bovina: aspectos clínicos, características do vírus e observações sobre vacinação. Arq. Esc. Vet. (Minas Gerais), 22: $213-216,1970$
28. ROPP, S.L.; JIN, Q.I.; KNIGHT, J.C.; MASSUNG, R.F. \& ESPOSITO, J.J. - PCR strategy for identification and differentiation of smallpox and other orthopoxviruses. J. clin. Microbiol., 33: 2069-2076, 1995.

29. SALLES-GOMES, L.F.; MAGALDI-JORDÃO, F.B.; ANGULO, J.J. et al. - An epidemiological study of vaccinia in man. II. The antibody response. Hospital (Rio de J.), 72: 801-877, 1967.

30. SALLES-GOMES, L.F.; CONCEIÇÃO, B.C.; GALLUZI, Y.D. et al. - Varíola. Diagnóstico etiológico de 1967 a 1970, no Instituto Adolfo Lutz. Rev. Inst. Adolfo Lutz, 31: 5-12, 1971.

31. SAMBROOK, J. \& RUSSEL, D.W. - Gel electrophoresis of DNA and pulsed-field agarose gel electrophoresis. In: SAMBROOK, J. \& RUSSEL, D.W., ed. Molecular cloning: a laboratory manual. 3. ed. New York, Cold Spring Harbor Laboratories, 2001. p. 5.4-5.86.

32. SCHATZMAYR, H.G.; LEMOS, E.R.; MAZUR, C. et al. - Detection of poxvirus in cattle associated with human cases in the State of Rio de Janeiro: preliminary report. Mem. Inst. Oswaldo Cruz, 95: 625-627, 2000.

33. SHANLEY, J.D. - Poxviruses. eMedicine Journal, April 18, 2002. [http:// www.emedicine.com/med/topic1903.htm]

34. SILVA, P.L.; COELHO, H.E.; VIANA, F.C. et al. - Surto de varíola bovina no município de Prata - MG. Arq. bras. Med. vet. Zoot., 38: 323-330, 1986.

35. SILVA, R.A. \& MORAES, L.T. - Nota sobre a ocorrência da varíola bovina (cow-pox) no Estado do Rio de Janeiro. I. Estudo da doença no Município de Três Rios. Veterinária (Rio de J.), 14: 31-35, 1960/1961.

36. SOUZA TRINDADE, G.; FONSECA, F.G.; MARQUES, J.J. et al. - Araçatuba virus: vaccinia-like virus associated with infection in human and cattle. Emerg. infect. Dis., 9: 155-160, 2003.

37. THOMPSON, J.D.; GIBSON, T.J.; PLEWNIAK, F.; JEANMOUGIN, F. \& HIGGINS, D.G. - The Clustal X windows interface: flexible strategies for multiple sequence alignment aided by quality analysis tools. Nucleic Acids Res., 25: 4876-4882, 1997.

38. UEDA, M.; TANAKA, H.; KISIELIUS, J.J. et al. - Importance of electron microscopy and its contribution to viral diagnosis. Virus Rev. Res., 3: 9-36, 1998.

39. VARÍOLA bovina contamina 37 pessoas em Lagoinha - Notícias da terra. O Estado de São Paulo, Suplemento Agrícola, (2461), G3, 8 de Janeiro de 2003.

40. VARÍOLA bovina fecha 30 fazendas no Vale do Paraíba - Reportagem local. Folha de São Paulo, Caderno Agrofolha, F4, 30 de outubro de 2001.

41. VARÍOLA bovina no Vale do Paraíba. Pesq. FAPESP, (81): 32, 2002.

42. VELLINI, L.L. - A varíola bovina (cowpox) no Estado de São Paulo e sua transmissão ao homem. Hospital (Rio de J.), 44: 247-252, 1953.

43. VELLINI, L.L. - A varíola bovina (cowpox) em São Paulo e sua transmissão ao homem. Hospital (Rio de J.), 47: 579-581, 1955

44. VELLINI, L.L. - A varíola bovina (cowpox) e o preparo da linfa vaccínica no Estado de São Paulo. São Paulo, 1957. (Tese Cátedra - Faculdade de Medicina Veterinária da Universidade de São Paulo).

45. WEIBLEN, R. - Vaccínia: varíola bovina e pseudovaríola. Rev. CFMV (Brasília), 8 (26 supl. Técnico): 37-43, 2002.

Received: 6 April 2004

Accepted: 6 October 2004 